\title{
Impact of Osun Elementary School Feeding and Health Programme (OMEALS) on the Enrolment and Retention of Rural Primary School Pupils in Osun State, Nigeria
}

\author{
*Olajubutu D. F. ${ }^{1}$, Adebayo B. O. ${ }^{2}$ and Olajubutu O. J. ${ }^{3}$ \\ *Corresponding Author's Email: diyiola8782@stu.ui.edu.ng \\ ${ }^{1,2}$ Department of Agricultural Extension and Rural Development, University of Ibadan, \\ Nigeria; ${ }^{3}$ Department of Primary Education Studies, University of Ilorin, Nigeria
}

\begin{abstract}
School Feeding Programmes are social safety net interventions providing educational and health benefits to vulnerable children in developing countries. This study assessed the impact of Osun Elementary School Feeding and Health Programme (O-MEALS) on the enrolment and retention of rural primary schools in Osun State. Multi stage sampling technique was used to select 188 respondents while data was collected through interview schedule. Percentages, Chi-square, PPMC and T-test were used for data analysis. Findings revealed that over half $(51.6 \%)$ of the respondents were male, aged $9.38 \pm 1.84$ years and majority $(83.0 \%)$ had a family size of 6-10 people. Food incentives $(\bar{x}=1.25)$, health challenge $(\bar{x}=0.69)$, and peer influence $(\overline{\mathrm{x}}=0.67)$ were major factors affecting school attendance. More than half (53.2\%) of the respondents had unfavourable perception towards the school feeding programme. Results showed a significant difference between pupils' enrolment $(\mathrm{t}=5.332, \mathrm{p}$ $=0.006)$ and retention rate $(\mathrm{t}=58.386, \mathrm{p}=0.000)$ before and after the commencement of $\mathrm{O}$ MEALS. Furthermore, pupils' enrolment and retention $(r=0.993, p=0.001)$ after the commencement of O-MEALS was significantly related. Food incentive was a major factor affecting school attendance, which fostered an improvement in the poor enrolment and retention previously experienced. Since a good number of the pupils possessed unfavourably perception towards the school feeding programme, it was recommended that effective monitoring be established to checkmate food vendors' activities in delivering quality and satisfactory services. Likewise, the Government's policies on school restructuring and levy, which had proved counterproductive, should be reviewed.
\end{abstract}

Keywords: School feeding programme, Osun Elementary School Feeding and Health Programme (O-MEALS), enrolment and retention, rural pupils, primary schools.

\section{INTRODUCTION}

School Feeding Programmes (SFPs) are critical interventions to mitigate poverty, stimulate school enrolment and enhance pupils' performance, especially in developing countries (Taylor and Ogbogu, 2016). They serve as social safety net instruments to provide both educational and health benefits to vulnerable children from food insecure families with low socio-economic status, as well as schools experiencing poor enrollment and attendance of students (Lawson, 2012; Aliu and Fawzia, 2014).

Almost 60 million children every day in developing countries are hungry and attend school on empty stomach, with about 40 percent domiciled in Africa (World Food programme, 2010; Akanbi, 2013). Ethiopia and Nigeria are countries in the Sub-Saharan Africa with the very high rate of malnutrition (Getahun, Urga, Ganebo and Nigatu, 2001; Adewara and 
Visser, 2011). Malnutrition, according to Grantham-McGregor and Ani (2001), affects the cognitive development of children and is also likely to result in poor attendance at school and ultimately leading to high withdrawal rate (Olusanya, 2010). United Nations Development Programme (2003) reported that up to $26 \%$ of boys and $30 \%$ of girls of primary school age in developing countries are not attending school. This was buttressed by Yunusa et al. (2012) that malnutrition disorders affect more than $42 \%$ of school children in Nigeria and account for $49 \%$ absenteeism of primary school age children. Consequently, out of the over 1 million school age children in Osun State, only half are currently enrolled in school (National Population Commission and ICF, 2008). SFPs are therefore notable for achieving the Sustainable Development Goals through its focus on reducing hunger, enhancing cognitive development, increasing school enrollment and improving business prospects for women and other local agriculture actors (Birdsall, Levine, and Ibrahim, 2005; Aigbedion, Chamorro, Duggan, and Fujiwara 2012).

Several African countries like Botswana, Côte d'Ivoire, Kenya, Ghana, Cape Verde, South Africa, Mali and Nigeria have overtime embarked on School Feeding Programmes, (Partnership for Child Development, 2016). The introduction of the School Feeding Programme into Nigeria can be traced to the Millennium Development Goals (MDGs) initiative in which Nigeria was one of twelve pilot countries invited to implement the programme. Consequently, the Federal Government of Nigeria came up with an enabling legislative backing for the execution of the Home Grown School Feeding and Health Programme through the Universal Basic Education Act in 2004 (Taylor and Ogbogu, 2016), stipulating that all State primary schools must provide a minimum of one meal a day to each pupil (PCD, 2016). In 2006, the national programme commenced a phased-pilot with the following 13 States: Bauchi, Cross River, Enugu, the Federal Capital Territory, Imo, Kano, Kebbi, Kogi, Nasarawa, Ogun, Rivers, and Yobe and Osun state (PCD, 2016).

The Osun Elementary School Feeding and Health Programme (O-MEALS), formerly known as the Home Grown School Feeding and Health Programme (HGSFP), was redesigned and launched on 30th April, 2012 after a comprehensive review (Osun elementary, 2018). It is one of the few surviving school meal programmes in Nigeria and is reputable as a model of good practice amongst other school feeding initiatives in Nigeria. The programme daily provides one mid-day school meal, serving over 252,000 primary school children in elementary grades 1-4 in all 1,382 public primary schools, to ensure a minimum of $33 \%$ of the recommended dietary intake of vitamins and nutrients (PCD, 2016). The objectives of OMEALS are framed in the National School Health Policy and captured as follows: (i) improvement of nutritional and health status of school children (ii) increasing school enrollment, retention, and completion (iii) stimulating job creation, local goods production, and income-generating activities of local farmers (iv) reducing the incidence of poverty and stimulating development of small and medium-scale enterprises (PCD, 2016; Yunusa et al., 2012).

Although few assessment studies on School Feeding Programme have been carried out in Osun state, however, adequate attention is yet to be accorded to investigating the impact of the programme among rural primary school pupils, whom according to Agbozo, Atitto and Abubakari (2017), have a higher risk of malnutrition and absenteeism from school. This study therefore aims to assess the Impact of Osun Elementary School Feeding and Health Programme (OMEALS) on the enrolment and retention of rural primary school pupils in Osun State. 


\section{Research objectives}

The main objective of the study is to assess the Impact of Osun Elementary School Feeding and Health Programme (OMEALS) on the Enrolment and Retention of Rural Primary School Pupils in Osun State. The specific objectives are to:

1. determine the personal characteristics of respondents

2. identify the factors affecting school attendance

3. determine respondents' perception towards O-MEALS

4. assess the school enrolment of respondents

5. assess the school retention rate of respondents

\section{Research hypotheses}

The following hypotheses stated in null form were tested:

$\mathrm{H}_{0} 1$ : There is no significant difference between respondents' school enrolment before and after the commencement of O-MEALS

$\mathrm{H}_{0}$ 2: There is no significant difference between respondents' school retention rate before and after the commencement of O-MEALS

$\mathrm{H}_{0} 3$ : There is no significant relationship between respondents' school enrolment and retention after the commencement of O-MEALS

\section{METHODS}

This research was conducted in Osun State, which is located in the south-western part of Nigeria, covering an area of approximately 14,875 square kilometers (Shaad, Jaisinghani, and Gelli, 2010). The State is made up of three agro-ecological zones: rainforest; derived savannah; and Guinea savannah (Adetayo and Babafunso, 2001) with smallholder farmers predominating the agricultural production system. Osun State has an estimated population of nearly 3.5 million (Federal Republic of Nigeria, 2009), with over 1 million being school age children, of which half are currently enrolled in school, and $49 \%$ of whom are girls (National Population Commission and ICF Macro, 2008).

The population for the study includes rural primary school pupils in Osun state. Multi stage sampling procedure was used to select a representative sample for the study. The first stage involved random sampling of two-third of the three senatorial districts in Osun state: Osun west and Osun central were selected. Afterwards, 10 percent of the 10 Local Government Areas in each senatorial district were randomly selected; Isokan south and Boripe Local Government Areas were selected respectively and the primary schools in these Local Government Areas were stratified into rural and urban schools. Also, 10 percent of the schools in the rural areas were randomly selected (Baptist Day primary school and Irewolede primary school from Boripe Local Government Area; St. Paul Anglican primary school, St. Mary Catholic primary school and Community elementary school were selected from Isokan south Local Government Area) and primary two, three and four classes were purposively selected for their ability to better understand and respond to the questions being asked by the enumerator. Finally, 30\% of pupils from primary two to primary four were random selection, to give a sample size of 188 respondents. Primary data was collected through the use of interview schedule and in-depth interview while Secondary data were obtained from school registers. Data were analysed using Chi square, Pearson Product Moment Correlation and Ttest. 
Table 3.1: Sampling procedure and sample size

\begin{tabular}{|c|c|c|c|c|c|c|}
\hline $\begin{array}{l}\text { Selected } \\
\text { Senatorial } \\
\text { Districts }\end{array}$ & $\begin{array}{l}\text { No of } \\
\text { L.G.A }\end{array}$ & $\begin{array}{l}\text { Selected } \\
\text { L.G.A } \\
(\mathbf{1 0 \%})\end{array}$ & $\begin{array}{l}\text { Total No } \\
\text { of Pry. } \\
\text { School }\end{array}$ & $\begin{array}{l}\text { No of } \\
\text { Rural } \\
\text { Schools }\end{array}$ & $\begin{array}{l}10 \% \text { of } \\
\text { Rural } \\
\text { Schools }\end{array}$ & $\begin{array}{l}30 \% \text { of } \\
\text { pupils in } \\
\text { Pry } 2-4\end{array}$ \\
\hline Osun West & 1010 & Isokan & 58 & 32 & 3 & 94 \\
\hline Osun Central & & Boripe & 34 & 19 & 2 & 94 \\
\hline Total & 20 & 2 & 92 & 62 & 5 & 188 \\
\hline
\end{tabular}

Source: Osun State Primary Education Board, 2018

\section{RESULTS AND DISCUSSION}

\section{Personal characteristics of the respondents}

The result in Table 4.1 reveals that more than half $(51.6 \%)$ of the respondents were male while less than half (48.4\%) were female. This is in agreement with a report by NPC and ICF (2008) that $49 \%$ of school age children in Osun state are girls. Also, over average $(51.1 \%)$ of the respondents were within the age range of 10-14 years while their mean age was $9.4 \pm 1.8$ years. Majority $(83.0 \%)$ of respondents had a family size of 6-10 people with the mean family size of $7.8 \pm 2.2$ people. The large household from which the students come from could negatively affect their access to adequate nutritional meals at home, considering the high cost of living and prices of food. More than half $(51.1 \%)$ of their parents were engaged in farming as their primary occupation.

Table 4.1: Distribution of respondents by personal characteristics

\begin{tabular}{lccc}
\hline Variable & Frequency & Percentage & Parameter \\
\hline Age & & & Mean $=9.38$ \\
$5-9$ & 92 & 48.9 & S.D $=1.84$ \\
$10-14$ & 96 & 51.1 & \\
Sex & & & Mode $=$ Male \\
Male & 97 & 41.6 & \\
Female & 91 & & Mode $=$ Pry 3 \\
Class & & 34.0 & \\
Primary 2 & 64 & 36.2 & \\
Primary 3 & 68 & 29.8 & Mean $=7.80$ \\
Primary 4 & 56 & & \\
Family size & & 10.6 & \\
1-5 & 20 & 83.0 & \\
6.-10 & 156 & 6.4 & \\
Above 10 & 12 & & \\
Parents' primary & & & \\
occupation & & 51.1 & \\
Farming & 96 & 2.7 & \\
Trading & 5 & 1.1 & \\
Teaching & 2 & 39.4 & \\
Artisan & 74 & 2.7 & \\
Civil Servant & 5 & 0.5 & \\
Medical Practitioner & 1 & 1.6 & \\
Cleric & 3 & 1.1 & \\
Night guard & 2 & & \\
\hline
\end{tabular}




\section{Factors affecting school attendance}

Table 4.2 reveals that food incentives $(\overline{\mathrm{x}}=1.25)$, health challenge $(\overline{\mathrm{x}}=0.69)$ and peer influence $(\overline{\mathrm{x}}=0.67)$ were the major factors affecting school attendance. Other factors include demand for family labour $(\overline{\mathrm{X}}=0.18)$, long distance to school $(\overline{\mathrm{X}}=0.13)$, personal dislike for school $(\overline{\mathrm{x}}=0.07)$, the need to work for money ( $\overline{\mathrm{x}}=0.06)$, parents' negative attitude toward education $(\overline{\mathrm{x}}=0.05)$, free school uniform and stationaries $(\overline{\mathrm{x}}=0.03)$, poverty $(\overline{\mathrm{x}}=0.02)$. This implies that food incentives, health challenge and peer influence were the major determinants of school attendance in the study area. Similarly, Dheressa (2011) identified illness as a major cause of absenteeism among pupils. The result reflects that food incentives could positively influence school enrollment and attendance. Asserting this, Yunusa et al. (2012) reported that a school meal programme can double primary school enrollment in one year and among the key beneficiaries are girls who otherwise may never be given the opportunity to learn.

Table 4.2: Distribution of respondents by factors affecting school attendance

\begin{tabular}{llllcc}
\hline Factors affecting school attendance & $\begin{array}{l}\text { To a great } \\
\text { extent }(\boldsymbol{\%})\end{array}$ & $\begin{array}{l}\text { To a lesser } \\
\text { extent }(\boldsymbol{\%})\end{array}$ & $\begin{array}{l}\text { Not at } \\
\text { all }(\boldsymbol{\%})\end{array}$ & Mean & Rank \\
\hline Food incentives & 54.3 & 16.5 & 29.30 & 1.25 & $1^{\text {st }}$ \\
Health challenge & 1.10 & 67.0 & 31.90 & 0.69 & $2^{\text {nd }}$ \\
Peer influence & 18.6 & 29.8 & 51.60 & 0.67 & $3^{\text {rd }}$ \\
Demand for family labour & 1.60 & 14.9 & 83.50 & 0.18 & $4^{\text {th }}$ \\
Long distance to school & 2.10 & 8.50 & 89.40 & 0.13 & $5^{\text {th }}$ \\
Personal dislike for school & 1.10 & 4.80 & 94.10 & 0.07 & $6^{\text {th }}$ \\
The need to work for money & 1.10 & 4.30 & 94.70 & 0.06 & $7^{\text {th }}$ \\
Parents' negative attitude toward education & 0.50 & 1.60 & 97.30 & 0.05 & $8^{\text {th }}$ \\
Free school uniform and stationaries & 0.50 & 1.60 & 97.90 & 0.03 & $9^{\text {th }}$ \\
Poverty & 0.50 & 1.10 & 98.40 & 0.02 & $10^{\text {th }}$ \\
\hline
\end{tabular}

\section{Respondents' perception towards O-MEALS}

The result obtained in Table 4.3.1 revealed that majority (73.4\%) of the respondents strongly disagreed that fruits are served daily, $60.6 \%$ strongly disagreed that if not for school meals, they would not have been eating up to three meals in a day. A little above average $(53.2 \%)$ strongly disagreed that their parents release them to attend school because of school meals and $43.6 \%$ strongly disagreed that they prefer school meals to what they are served at home. Half $(50 \%)$ of the respondents agreed that school meals are sometimes served without meat, fish, egg or chicken, that fruits are sometimes not served $(68.1 \%)$ and they $(64.4 \%)$ eat three meals a day, with or without school meals. On the positive, they strongly agreed that school meals are usually served on time $(50.5 \%)$, get to them every day $(55.3 \%)$ and are very tasty $(52.1 \%)$ and $41.5 \%$ of the respondents strongly agreed that school meals motivate them to go to school.

Moreover, the categorization of perception scores as represented in Table 4.3.2 revealed that more than half $(53.2 \%)$ of the respondents had unfavourable perception towards Osun Elementary School Feeding and Health Programme (O-MEALS) while the remaining 46.8\% had favourable perception towards the programme. This result implies that the students are not satisfied with the meal being provided through the home grown school feeding programme. Though, it was earlier reported in the study that food incentive was a major factor influencing the attendance of school attendance, an unfavourable perception could therefore render the incentive fruitless. 
Table 4.3.1: Frequency distribution based on respondents' perception towards O-MEALS

\begin{tabular}{|c|c|c|c|c|c|}
\hline Perception Statements & $\begin{array}{l}\text { Strongly } \\
\text { Agree }(\%)\end{array}$ & $\begin{array}{l}\text { Agree } \\
(\%)\end{array}$ & $\begin{array}{l}\text { Undecided } \\
(\%)\end{array}$ & $\begin{array}{l}\text { Disagree } \\
(\%)\end{array}$ & $\begin{array}{l}\text { Strongly } \\
\text { Disagree }(\%)\end{array}$ \\
\hline School meals motivate me to go to school & 41.5 & 32.4 & 0.00 & 6.40 & 19.7 \\
\hline I do not like the meals served & 6.40 & 11.2 & 0.50 & 34.6 & 47.3 \\
\hline I prefer school meals to what I'm served at home & 27.7 & 12.8 & 3.20 & 12.8 & 43.6 \\
\hline School meals are usually tasteless & 5.30 & 6.40 & 1.60 & 36.2 & 50.5 \\
\hline I assimilate faster after eating school meals & 17.0 & 35.6 & 2.10 & 26.1 & 19.1 \\
\hline The fruits served are sometimes bad & 8.50 & 13.3 & 4.30 & 29.3 & 44.7 \\
\hline Meals served are usually too small & 34.6 & 20.7 & 5.30 & 14.9 & 24.5 \\
\hline School meals does not motivate me to go to school & 20.2 & 10.6 & 1.10 & 34.0 & 34.0 \\
\hline I prefer home meals to school meals & 47.3 & 13.8 & 2.70 & 16.5 & 19.7 \\
\hline School meals are often served late & 3.20 & 8.50 & 1.60 & 36.7 & 50.0 \\
\hline I like the meals served & 43.6 & 46.8 & 0.00 & 4.80 & 4.80 \\
\hline School meals are very tasty & 52.1 & 41.0 & 1.60 & 1.10 & 4.30 \\
\hline $\begin{array}{l}\text { If not for school meals, I would not have been } \\
\text { eating up to three meals in a day. }\end{array}$ & 3.20 & 8.00 & 2.10 & 26.1 & 60.6 \\
\hline The fruits served are always fresh & 41.0 & 36.7 & 3.70 & 9.60 & 9.00 \\
\hline Meals served are usually satisfactory & 39.9 & 36.7 & 1.10 & 11.7 & 10.6 \\
\hline School meals are usually served on time & 50.5 & 41.5 & 1.60 & 5.90 & 0.50 \\
\hline I do not assimilate faster after eating school meals & 12.2 & 30.9 & 1.60 & 34.6 & 20.7 \\
\hline $\begin{array}{l}\text { My parents release me to attend school because of } \\
\text { school meals }\end{array}$ & 9.60 & 12.8 & 1.60 & 22.9 & 53.2 \\
\hline School meals get to me every day & 55.3 & 36.2 & 0.00 & 5.30 & 3.20 \\
\hline $\begin{array}{l}\text { School meals are sometimes served without meat, } \\
\text { fish, egg or chicken. }\end{array}$ & 18.1 & 50.0 & 2.70 & 14.9 & 14.4 \\
\hline Fruits are served daily & 1.10 & 1.10 & 0.00 & 24.5 & 73.4 \\
\hline I eat three meals a day, with or without school meals & 64.4 & 22.9 & 2.10 & 6.40 & 3.70 \\
\hline Fruits are sometimes not served & 68.1 & 28.2 & 0.00 & 0.50 & 3.20 \\
\hline There are days when school meals do not get to me & 5.30 & 2.10 & 1.60 & 29.3 & 61.7 \\
\hline $\begin{array}{l}\text { I don't like being absent from school because of } \\
\text { school meals }\end{array}$ & 16.0 & 38.3 & 2.10 & 23.4 & 20.2 \\
\hline $\begin{array}{l}\text { School meals are never served without meat, fish, } \\
\text { egg or chicken. }\end{array}$ & 13.8 & 14.9 & 2.70 & 38.8 & 29.8 \\
\hline
\end{tabular}

Table 4.3.2: Categorization of respondents based on their perception towards O-MEALS

\begin{tabular}{lllll}
\hline Perception & Score & Frequency & Percentage (\%) & Parameters \\
& & & & \\
\hline Unfavourable & $\leq 82.48$ & 100 & 53.2 & Mean = 82.49, S.D = 10.80 \\
Favourable & $\geq 82.49$ & 88 & 46.8 & Min = 40, Max = 126 \\
Total & & $\mathbf{1 8 8}$ & $\mathbf{1 0 0 . 0}$ & \\
\hline
\end{tabular}




\section{School enrolment}

Findings in Table 4.4 showed a decline in the enrollment of pupils prior to the commencement of O-MEALS (2006 to 2011) in Osun state. Baptist Day primary school experienced a decline (from 146 to 135 pupils) between 2006 and 2011, Irewolede primary school (from 168 to 135 pupils), St. Paul Anglican primary school (from 138 to 106 pupils), St. Mary Catholic primary school (from 118 to 117 pupils) and Community elementary school (from 347 to 236 pupils). This implies that the school enrolment in Osun state prior to the introduction of school feeding programme was poor, hence, the probability of increased enrolment through school feeding incentives was high.

After school feeding programme was introduced, schools experienced notable increment in the enrolment of pupils. Baptist Day primary school had an enrolment increase from 110 to 253 pupils between 2012 and 2016 but a decline (from 253 to 198 pupils) in 2017. Irewolede primary school had an increased enrolment from 179 to 258 pupils between 2012 and 2017 but a decline (177 pupils) in 2015. St. Paul Anglican primary school had an enrolment increase from 99 to 100 pupils between 2012 and 2013, a decline from 91 to 63 pupils (2014 and 2016) and an increase (from 63 to 85 pupils) between 2016 and 2017. St. Mary Catholic primary school experienced an enrolment increase from 101 to 140 pupils (2012-2013) but a continuous decline in enrolment (from 123 to 91 pupils) between 2014 and 2017. Community elementary school had an enrolment increase (from 270 to 419 pupils) between 2012 and 2015, however, there was an enrolment decline (from 259 to 228 pupils) between 2016 and 2017.

Summarily, the total enrolment revealed an increase in enrolment (759, 979, 995, 1012 pupils) between 2012 and 2015. According to Taylor and Ogbogu (2016), school feeding programme resulted in an increase in pupils' enrolment, retention, regularity, punctuality in school attendance and it has enhanced pupils' performance in curricular and extracurricular activities. However, the result reveals a decline (898, 860 pupils) between 2016 and 2017. This reason for the decline was revealed during an in-depth interview with a staff of Community elementary school, stating that:

"there has been a withdrawal of students from public to affordable private schools due to some parent's unwillingness to pay the government levy of five hundred naira (\$500) per term which was introduced in 2017”.

Table 4.4: School enrolment before and after the commencement of O-MEALS

\begin{tabular}{llllllll}
\hline & Year & Baptist & Irewolede & St. Paul & St. Mary & Community & Total \\
\hline \multirow{6}{*}{ Before } & $\mathbf{2 0 0 6}$ & 146 & 168 & 138 & 118 & 347 & 917 \\
& $\mathbf{2 0 0 7}$ & 151 & 204 & 149 & 115 & 451 & 1070 \\
& $\mathbf{2 0 0 8}$ & 135 & 190 & 125 & 128 & 277 & 855 \\
& $\mathbf{2 0 1 0}$ & 178 & 159 & 121 & 125 & 245 & 828 \\
& $\mathbf{2 0 1 1}$ & 148 & 129 & 131 & 125 & 229 & 762 \\
After & $\mathbf{2 0 1 2}$ & 110 & 135 & 106 & 117 & 236 & 729 \\
& $\mathbf{2 0 1 3}$ & 134 & 179 & 99 & 101 & 270 & 759 \\
& $\mathbf{2 0 1 4}$ & 170 & 217 & 91 & 123 & 419 & 979 \\
& $\mathbf{2 0 1 5}$ & 210 & 177 & 78 & 128 & 394 & 987 \\
& $\mathbf{2 0 1 6}$ & 253 & 230 & 63 & 93 & 259 & 898 \\
& $\mathbf{2 0 1 7}$ & 198 & 258 & 85 & 91 & 228 & 860 \\
\hline
\end{tabular}

Source: School Register, 2006-2017 


\section{School retention}

Table 4.5 revealed a decline in the retention of pupils prior to the commencement of $\mathrm{O}$ MEALS (2006 to 2011) in Osun state. Baptist Day primary school experienced a decline (from 135 to 114 pupils) between 2006 and 2011, Irewolede primary school (from 162 to 118 pupils), St. Paul Anglican primary school (138 to 103 pupils), St. Mary Catholic primary school (from 109 to102 pupils) and Community elementary school (from 307 to 217 pupils). This implies that the pupils' retention in Osun state prior to the introduction of school feeding programme was very poor, hence, the necessity of such programme.

After school feeding programme was introduced, schools experienced increment in the retention of pupils. Baptist Day primary school had a retention increase from 83 to 218 pupils between 2012 and 2016 but a decline (from 218 to 175 pupils) in 2017. Irewolede primary school had an increase in retention from 167 to 243 pupils between 2012 and 2017 but a decline (166 pupils) in 2015. St. Paul Anglican primary school had a retention increase from 81 to 93 pupils between 2012 and 2013 but a continuous decline (from 91 to 59 pupils) between 2014 and 2017. St. Mary Catholic primary school experienced an increase in retention from 91 to 107 pupils between 2012 and 2015 but a decline (68 to 67 pupils) between 2016 and 2017. Community elementary school had a retention increase (from 224 to 318 pupils) between 2012 and 2015, however, there was a decline from 215 to 185 between 2016 and 2017. The total retention indicates an increase in retention $(646,865,883,853$ pupils) between 2012 and 2015 but a decline (780, 731 pupils) between 2016 and 2017.

Conclusively, the retention rate in Table 4.6 indicates an increase (from $85.1 \%$ to $88.4 \%$, $88.6 \%$ and $88.9 \%$ ) between 2012 and 2015 . However, the result reveals a decline from $86.9 \%$ to $85.0 \%$ between 2016 and 2017 . This could be attributed to the report obtained from the students that some of their classmates who benefitted from the school feeding programme were found absconding from school during examination periods. This shows that most of the student are motivated to come to school as a result of the feeding being provided. Therefore, it is expedient to put in place other measures that encourages students' interest in education. Such measures could encourage their attendance during exam periods. Also, a teacher from St. Paul Anglican primary school reported during an in-depth interview that:

"the restructuring of public primary schools by the Osun state government during the 2013/2014 session, whereby, elementary schools consists of Primary one to four only and middle-school consists of primary 4, primary 5 and junior secondary pupils, has led to the withdrawal of the younger pupils in the former category, at the point of graduation of their elder ones to middle-school".

She further explained that,

"those parents prefer the younger ones to attend schools that are not too far from those of their siblings, who take them to school every morning, hence, they transfer them to another public school or to an affordable private school that is close to the school of their elder siblings".

Another teacher from Community elementary school, reported that:

"there has been a withdrawal of students from public to affordable private schools due to some parent's unwillingness to pay the government levy of five hundred naira (\$500) per term which was introduced in 2017”" 
.Table 4.5: School retention before and after the commencement of O-MEALS

\begin{tabular}{llllllll}
\hline & Year & Baptist & Irewolede & St. Paul & St. Mary & Community & Total \\
\hline \multirow{6}{*}{ Before } & $\mathbf{2 0 0 6}$ & 135 & 162 & 138 & 109 & 307 & 851 \\
& $\mathbf{2 0 0 7}$ & 143 & 184 & 149 & 107 & 382 & 965 \\
& $\mathbf{2 0 0 8}$ & 128 & 179 & 122 & 114 & 250 & 793 \\
& $\mathbf{2 0 1 0}$ & 156 & 148 & 113 & 95 & 226 & 738 \\
& $\mathbf{2 0 1 1}$ & 110 & 123 & 117 & 114 & 212 & 676 \\
& $\mathbf{2 0 1 2}$ & 83 & 118 & 103 & 102 & 217 & 654 \\
& $\mathbf{2 0 1 3}$ & 114 & 167 & 81 & 91 & 224 & 646 \\
& $\mathbf{2 0 1 4}$ & 155 & 199 & 93 & 122 & 361 & 865 \\
& $\mathbf{2 0 1 5}$ & 188 & 166 & 74 & 107 & 331 & 883 \\
& $\mathbf{2 0 1 6}$ & 218 & 219 & 62 & 68 & 215 & 853 \\
& $\mathbf{2 0 1 7}$ & 175 & 243 & 59 & 67 & 185 & 729 \\
\hline
\end{tabular}

Source: School Register, 2006-2017

Table 4.6: Retention rate before and after the commencement of O-MEALS

\begin{tabular}{ccccc}
\hline & Year & Total Enrolment & Total Retention & Retention rate (\%) \\
\hline \multirow{6}{*}{ Before } & $\mathbf{2 0 0 6}$ & 917 & 851 & \\
& $\mathbf{2 0 0 7}$ & 1070 & 965 & $92.8 \%$ \\
& $\mathbf{2 0 0 8}$ & 855 & 793 & $90.2 \%$ \\
& $\mathbf{2 0 0 9}$ & 828 & 738 & $92.7 \%$ \\
& $\mathbf{2 0 1 0}$ & 762 & 676 & $89.1 \%$ \\
& $\mathbf{2 0 1 1}$ & 729 & 654 & $88.7 \%$ \\
& $\mathbf{2 0 1 2}$ & 759 & 646 & $85.7 \%$ \\
& $\mathbf{2 0 1 3}$ & 979 & 865 & $88.4 \%$ \\
& $\mathbf{2 0 1 4}$ & 995 & 883 & $88.7 \%$ \\
& $\mathbf{2 0 1 5}$ & 1012 & 853 & $88.9 \%$ \\
& $\mathbf{2 0 1 6}$ & 898 & 780 & $86.9 \%$ \\
& $\mathbf{2 0 1 7}$ & 860 & 731 & $85.0 \%$ \\
\hline
\end{tabular}

Source: School Register, 2006-2017

\subsection{Hypotheses testing}

Difference between respondents' enrolment before and since the commencement of $O$ MEALS

The result of hypothesis one which stated that there is no significant difference between respondents' enrolment before and after the commencement of O-MEALS in Table 4.7 revealed that a significant difference exists $(\mathrm{t}=5.332, \mathrm{p}=0.006)$. This implies that enrollment varies before and since the commencement of O-MEALS, which could be traced to the increase in school enrolment after the introduction of the school feeding programme. This is in consonance with findings by Taylor and Ogbogu (2016) that school feeding programme resulted in an increase in pupils' enrolment. Akanbi (2013) posited that School 
Feeding Programme is vital in nourishing children as well as promoting enrolment and regular attendance because parents are motivated to send their children to school rather than keeping them at home to work or care for siblings.

Table 7: t-Test analysis of the difference between respondents' enrolment before and after the commencement of O-MEALS

\begin{tabular}{lllll}
\hline Variable & $\mathrm{t}$ & $\mathrm{df}$ & $\mathrm{p}$-value & Decision \\
\hline Enrolment & 5.332 & 4 & 0.006 & $\mathrm{~S}$ \\
\hline
\end{tabular}

Significant at $\mathrm{P}<0.05, \mathrm{~N}=188$

Difference between respondents' retention rate before and after the commencement of O-MEALS

The result of hypothesis two which stated that there is no significant difference between respondents' retention rate before and since the commencement of O-MEALS in Table 4.8 reveals that a significant difference exists $(\mathrm{t}=58.386, \mathrm{p}=0.000)$. This implies that retention rate varies before and since the commencement of O-MEALS, which could be traced to the initial increase in the students' retention rate after the introduction of the programme. This is in consonance with findings by Taylor and Ogbogu (2016) that school feeding programme resulted in an increase in pupils' retention.

Table 4.8: t-Test analysis of the difference between respondents' retention rate before and after the commencement of O-MEALS

\begin{tabular}{lllll}
\hline Variable & $\mathrm{t}$ & $\mathrm{df}$ & $\mathrm{p}$-value & Decision \\
\hline Enrolment & 58.386 & 4 & 0.000 & $\mathrm{~S}$ \\
\hline Significant at $\mathrm{P}<0.05, \mathrm{~N}=188$ & & &
\end{tabular}

Relationship between respondents' enrolment and retention after the commencement of O-MEALS

The correlation analysis of hypothesis three which stated that there is no significant relationship between respondents' enrolment and retention since the commencement of $\mathrm{O}$ MEALS in Table 4.9 indicates a significant relationship $(r=0.993, p=0.001)$ between school enrolment and retention. This implies that O-MEALS has an influence on pupils' enrolment and retention in the school. According to Mkanyika (2014), School Feeding Programmes help retain pupils in school through increased enrolment, attending school regularly, participating in class and hence lowering the dropout rate,

Table 4.9: Pearson Product Moment Correlation analysis showing the relationship enrolment and retention since the commencement of O-MEALS

\begin{tabular}{llll}
\hline Variable & r value & p-value & Decision \\
\hline Enrolment and Retention & 0.993 & 0.001 & $\mathrm{~S}$ \\
\hline
\end{tabular}

Significant at $\mathrm{P}<0.05, \mathrm{~N}=188$ 


\section{Conclusion}

The poor pupils' enrolment and retention situation previously experienced in Osun state witnessed an improvement after the introduction of school feeding programme. There was an evident increase in the total enrolment and retention rate between 2012 and 2015 but a decline between 2016 and 2017, which was attributed to some counterproductive government policies that were later introduced. Although food incentives, alongside health challenge and peer influence were major factors affecting school attendance, still, more than half of the respondents had unfavourable perception towards the Osun Elementary School Feeding and Health Programme (O-MEALS). This was attributed to the poor food quality and unsatisfactory services rendered by the food vendors.

\section{Recommendations}

1. Effective monitoring system should be put in place to ensure that the food vendors comply with the programme plan of serving fruits to the pupils on a daily basis.

2. Adequate measures should also be put in place to checkmate the activities of food vendors so as to ensure that a satisfactory quantity of food is being served to the pupils.

3. Primary education should be made completely free in rural government schools; hence, the government levy of five hundred naira ( $\$ 500)$ per term that was introduced in 2017 should be reviewed.

4. The re-structuring of public primary schools into elementary school (primary 1-4) and middle school (primary 5, 6 and junior secondary 1-3) in Osun State should be reviewed considering its counterproductive effect on pupils' enrolment and retention. 


\section{REFERENCES}

Adetayo, A. S. and Babafunso, S. E. (2001). Comparison of the performance of Nigerian indigenous chickens from three agro-ecological zones. Livestock Research for Rural Development, 13(2): 1-6. Retrieved on January 3, 2018, from URL http://www.lrrd.org/lrrd13/2/aded132.htm

Adewara, S. O. and Visser, M. (2011). Use of anthropometric measures to analyze how sources of water and sanitation affect children's health in Nigeria. Environment for Development Discussion Paper Series. Retrieved on January 3, 2018, from URL http:/ /www.efdinitiative.org/sites/default/files/efd-dp-11-02_posted.pdf.

Agbozo, F., Atitto, P. and Abubakari, A. (2017). Nutritional status of pupils attending public schools with and without school feeding programme in Hohoe municipality, Ghana. Journal of Food and Nutrition Research, 5(7): 467-474.

Aigbedion, A., Chamoro, P., Duggan, R. and Fujiwara, K. (2012). Osun state home grown school feeding programme: improving sustainability through increased local farmer participation. London, Partnership for development, HGSF working paper series, 12: 44pp. Retrieved on March 10, 2018, from URL www.hgsf-global.org.

Akanbi, G. O. (2013). Home grown school feeding and health programme in Nigeria: an innovative approach to boosting enrolment in public primary schools - a study of Osun state, 2002-2010. The African Symposium, 11(2): 8-12.

Aliu, M. and Fawzia, S. (2014). Assessing Ghana school feeding programme on the enrollment of beneficiary schools in the tamale metropolitan assembly of northern Ghana. International Journal of Economics, Commerce and Management, 2 (10). 130. Retrieved on March 10, 2018, from URL http://ijecm.co.uk/

Birdsall, L. R., Levine, A. and Ibrahim, A. (2005). Towards universal basic education: investments, incentives and institutions. European Journal of Education, 40 (3): 337 349, DOI: http://dx.doi.org/10.1111/j.1465-3435.2005.00230.x

Dheressa, D. K. (2011). Education in Focus: Impacts of School Feeding Programme on School

Participation: A case study in Dara Woreda of Sidama zone, Southern Ethiopia. Retri eved on June 6, 2018, from URL https://brage.bibsys.no/xmlui/handle/11250/187763.

Federal Republic of Nigeria (2009). Legal notice on publication of 2006 census final results. Abuja, Government Official Gazette, 96 (2). Retrieved on June 21, 2018, from URL http://placng.org/Legal\%20Notice\%20on\%20Publication\%20of\%202006\%20C ensus\%20Final\%20Results.pdf

Getahun, Z., Urga, K., Ganebo, T. and Nigatu, A. (2001). Review of the status of malnutrition and trends in Ethiopia. Ethiopian Journal of Health Development, 15: $55-74$.

Grantham-McGregor, S. M. and Ani, C. (2001). A review of studies on the effect of iron deficiency on cognitive development in children. Journal of Nutrition, 131: 649-68. 
Lawson, T. M. (2012). Impact of school feeding programmes on educational, nutritional, and agricultural development goals: a systematic review of literature. Retrieved on June 21, 2018, from https://ageconsearch.umn.edu/bitstream/142466/2/2012LawsonPlanB. pdf

Mkanyika, A. M. (2014). Influence of school feeding programme on pupils participation in public primary schools in flood prone areas of Garsen division, Tana delta district, Kenya. Retrieved on June 25, 2018, from URL http://erepository.uonbi.ac.ke/handle/1 $\underline{1295 / 77395}$.

National Population Commission (NPC) and ICF Macro (2008). Nigeria Demographic and Health Survey 2008. Retrieved on January 12, 2018, from URL http://www.measured hs.com/pubs/pdf/FR222/FR222.pdf

Olusanya, J. O. (2010). Assessment of the food habits and school feeding programme of pupils in a rural community in Odogbolu local government area of Ogun State, Nigeria. Pakistan Journal of Nutrition, 9 (2): 198-204.

Osun Elementary School Feeding and Health Programme (2018). Retrieved on March 3, 2018, from URL http://osun.gov.ng/education/omeals/\#.

Partnership for Child Development (2016). Global School Feeding Sourcebook: Lessons from

14 Countries. London, Imperial College Press, 507pp. Retrieved on July 10, 2018, fro m URL http://www.worldscientific.com/worldscibooks/10.1142/p1070

Shaad, B., Jaisinghani, N. and Gelli, A. (2010). Osun State Home Grown School Feeding and Healt Programme Case Study. PCD, London. Retrieved on February 23, 2018, from URL http://hgsfglobal.org/en/component/docman/doc_details/94-osun-state-hgsfandhealth-programme-case-study.

Taylor A. D. and Ogbogu C. O. (2016). The Effects of School Feeding Programme on Enrolment and Performance of Public Elementary School Pupils in Osun State. World Journal of Education, 6 (3): 39 - 47.

United Nations Development Programme (2003). Human development report. New York, Oxford University Press, 44pp. Retrieved on June 9, 2018, from URL http://hdr.undp. org/sites/default/files/hdr_2003_summary_en.pdf

World Food Programme (2010). School meals. Rome, WFP, 25pp. Retrieved on January 7 , 2018, from URL http://www.wfp.org/schools_meals.

Yunusa I., Gumel A. M, Adegusi K. and Sherif A. (2012). School Feeding Programme in Nigeria: A Vehicle for Nourishment of Pupils. The African Symposium: An online journal of the African Educational Research Network; 12 (2): 104-110. 